\author{
Asian Journal of Economic Modelling \\ $\operatorname{ISSN}(e): \quad 2312-3656$ \\ $\operatorname{ISSN}(p): \quad 2313-2884$ \\ DOI: $10.18488 /$ journal.8.2021.93.199.213 \\ Vol. 9, No. 3, 199-213. \\ (C) 2021 AESS Publications. All Rights Reserved. \\ URL: wrww.aessweb.com
}

\title{
THE GOVERNANCE AND TOURISM: A CASE OF DEVELOPING COUNTRIES
}

\author{
Rana Ejaz Ali Khan ${ }^{1+}$ \\ Tusawar Iftikhar \\ Ahmad $^{2}$ \\ Jaweria Haleem ${ }^{3}$
}

\author{
'Professor and Chairman, Department of Economics, The Islamia University \\ of Bahawalpur, Bahawalpur, Pakistan. \\ 'Assistant Professor, Department of Economics, The Islamia University of \\ Bahawalpur, Bahawalpur, Pakistan. \\ ${ }^{3}$ Visiting Lecturer, Department of Economics, The Islamia University of \\ Bahawalpur, Bahawalpur, Pakistan.
}

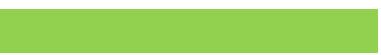

Article History

Received: 23 February 2021

Revised: 18 May 2021

Accepted: 6 July 2021

Published: 25 August 2021

Keywords

Tourism

Governance

Economic growth

Terrorism

Corruption

Trade openness.

JEL Classification:

L83, L88, C33.

\begin{abstract}
Tourism is a rapidly growing industry globally and it is contributing a significant part in the GDP of the economies. In the literature, a variety of determinants of tourism are discussed theoretically and empirically but the effect of national governance on tourism is rarely discussed. This study investigates the effect of governance on tourism development in a panel of 65 developing economies for the time period of 2000-2015. Tourism development is measured by an index of three components, i.e. spending by international tourists, spending by local tourists and tourism's share in total employment in the economy. For governance an index is constructed based on indicators of government effectiveness, political stability, regulatory quality, rule of law, and voice and accountability. Data has been taken from World Development Indicators (WDI), Worldwide Governance Indicators (WGI) and World Travel and Tourism Council (WTTC). Generalized Method of Moment (GMM) estimation indicates that governance positively influence tourism development and its components, i.e. foreign visitors spending, domestic tourist spending and contribution of tourism in employment. The indicators of governance, i.e. government effectiveness, political stability, regulatory quality, rule of law and voice and accountability also positively affect tourism development. Terrorism, environmental degradation and corruption have shown adverse effect on tourism development as well as components of tourism development. The economic growth and trade openness have encouraging effect on tourism development and its comments. It is concluded that through good governance tourism may be developed but terrorism and corruption are needed to be eliminated.
\end{abstract}

Contribution/ Originality: A bulk of literature exists on impact of different components of governance on tourism but none of the studies has analyzed the composite effect of governance indicators. The current study has contributed by estimating the impact of governance index on tourism along with components of governance.

\section{INTRODUCTION}

Tourism has quickly become an important source of economic development of the countries (Adnan \& Ali, 2013; Balaguer \& Cantavella-Jorda, 2002; Can \& Gozgor, 2018; Gokovali \& Bahar, 2006; Gokovali., 2010; Katircioğlu., 2011; Khalil, Kakar, \& Malik, 2007)1. It has shown positive impact on different sectors of the economies like employment (Brown \& Hall, 2008), women empowerment (Nassani, Aldakhil, Abro, Islam, \& Zaman, 2019) and 
macroeconomic balances (Richter \& Steiner, 2008). The tourism also contributes in rural development (Islam \& Carlsen, 2012) and decreases regional inequality (Lv, 2019).

The global economies and particularly the developing economies are struggling to increase their inbound tourism. How they can enhance such type of tourism is the area of interest for the researchers. The literature has identified a full range of determinants of tourism. Majority of the work is concerned with economic determinants, like the economic growth or level of development --- GDP or GDP per capita --- (Demir \& Gozgor, 2019; Khalil et al., 2007; Naudé \& Saayman, 2005; Saha., Su, \& Campbell, 2017; Yap \& Saha, 2013), tourism infrastructure, urbanization, marketing and information (Naudé \& Saayman, 2005), exchange rate or depreciation of currency (Demir \& Gozgor, 2019; Saha. et al., 2017; World Bank., 2018b), international trade (Demir \& Gozgor, 2019; Kulendran \& Wilson, 2000; Shan \& Wilson 2001) and technology and infrastructure (Zhang \& Jensen, 2007). Some of the studies have mainly focused on social, cultural and environmental determinants of tourism by including the variables like historical and natural heritage (Yap \& Saha, 2013), travel risk (Fischhoff, De Bruin, Perrin, \& Downs, 2004), world heritage sites ( $\mathrm{Su} \& \mathrm{Lin}$, 2014), cultural similarity (Cheung \& Saha, 2015) and temperate climate (Poprawe, 2015). A number of studies has probed the institutional determinants, like political stability (Fischhoff et al., 2004; Fletcher \& Morakabati, 2008), freedom of media (Demir \& Gozgor, 2019), trust and power (Nunkoo, Ramkinsoon, \& Gursoy, 2012), freedom of press (Das \& Dirienzo, 2009), government stability, external conflicts, bureaucratic quality, civil liberties, political freedom, economic freedom (Saha. et al., 2017), government effectiveness, absence of violence (Steyn \& Vuuren, 2016), corruption (Poprawe, 2015; Yap \& Saha, 2013), terrorism (Afonso-Rodríguez, 2017; Yap \& Saha, 2013) environment conservation and degradation (Klein \& Osleeb, 2010; Rasekhi \& Mohammadi, 2015), political violence (Neumayer, 2004) and democracy (Antonakakis, Dragouni, Eeckels, \& Filis, 2016)2. The political instability, corruption and terrorism are frequently analyzed for different economies or groups of the economies. Demir and Gozgor (2019) stressed the need for further work on tourism and institutional quality as well as its indicators as they may be important drivers of tourism. The institutional quality is one of the measurement dimensions of governance.

The governance measured by varying criterion contributes in development of different sectors of the economy. For instance, the elimination of income inequality (Shafique, Haq, \& Arif, 2006), human development (Ahmad \& Saleem, 2014) and economic growth (Roy, 2005) are attributed to good governance. How the governance contributes to tourism development in developing economies is the question to be answered by the current study ${ }^{3}$. Governance or the institutional quality express the critical part of the soft infrastructure of the economy (North, 1990; Williamson, 1979). It is argued that governance may affect the supply and demand of international tourism. The good governance decreases the uncertainty and transaction costs of tourism services on the supply side. However, on the demand side it affects the branding of tourist destinations (Kim, Saha, Vertinsky, \& Park, 2018). A few number of studies has attempted to see the impact of governance or components of governance on tourism. For instance, the political violence (Fielding \& Shortland, 2011), components of governance (Steyn \& Vuuren, 2016) and national institutional quality (Kim et al., 2018) on tourism have been probed in the literature. A comparatively larger number of studies has focused on political stability. These studies have focused on governance or components of governance for individual economies or groups of economies as determinants of tourism. To make the results robust the current study has focused on developing economies to analyze the role of governance in tourism using the index of indicators of tourism termed as tourism development comprising of foreign visitors spending, domestic

\footnotetext{
${ }^{2}$ The studies concerned with components of governance cover unidimensional concept of governance, while the multidimensional aspect is mostly ignored.

${ }^{3}$ Here we are concerned with national governance, although tourism governance has been seen by a large variety of literature. Mosedale (2014) observed that literature has overlooked the important impact of overall institutional quality on tourism.
} 
tourists spending and tourism contribution in employment ${ }^{4}$. The components of governance have significance in policy formation so impact of components of governance, i.e. government effectiveness, political stability, regulatory quality, rule of law, and voice and accountability on tourism development is also the part of the analysis ${ }^{5}$. Similarly, to make the results robust the impact of governance on indicators of tourism development is also probed. The major objective of the current study is to analyze the impact of governance tourism development in developing economies.

\section{LITERATURE REVIEW}

A strand of literature analyzed the determinants of tourism ranging from local attractions to international phenomena like financial crisis, terrorism and globalization. For instance, Goymen (2000) found that in Turkey, tourism has been interacting with social, economic and political components of the polity. Fayos-Sola (2002) analyzed the interaction of globalization, tourism policy and tourism education and found the positive impact of globalization on tourism. Naudé and Saayman (2005) found that political constancy, infrastructure of tourism and level of development of destination country attract the international tourists in Africa. Fletcher and Morakabati (2008) investigated the effects of terrorism and political unrest on tourism (number of tourist arrivals and the volume of tourism receipts) in Kenya and Fiji and concluded that political instability had more severe impact on tourism than terrorist attacks. Klein and Osleeb (2010) analyzed the determinants of coastal tourism of Florida beach. Number of hotels, eating and drinking places and museums collectively were used as a proxy of tourism. The study concluded that environmental conservation is an important determinant of coastal tourism. The beach nourishment projects (environmental protection) enhance the earnings of the tourism sector in Florida beach counties. The focus of current study is to see the impact of national governance on tourism, so the studies concerned with governance, components of governance or the proxies of the governance are covered in this review. The researchers have used the components of governance like control of corruption, political instability and government effectiveness as explanatory variables but they have not termed them as governance. For instance, Neumayer (2004) estimated the impact of different forms of political violence like human rights violation, conflict and politically motivated violent events on tourism for global sample through fixed effect panel estimation and dynamic GMM. All forms of political violence negatively impact tourist arrivals empirically evidenced by both techniques. A substantial increase in political violence decreases the tourist arrival by one quarter. The analysis further confirmed that autocratic regimes do not restrict tourism as long as they do not resort to political violence and are regarded as stable. Yap and Saha (2013) analyzed the impact of political instability, terrorism and corruption on tourism for a panel of 139 economies, particularly focusing on the UNESCO-listed heritage destinations. They concluded that political instability decreases tourist arrival and tourism revenue but tourist arrival is affected with lesser intensity as compared to tourism revenue. Terrorism also negatively influence tourism even in the presence of heritage, although weakly than political instability. The corruption has no adverse effects on number of arrivals, particularly for the countries having historical and natural heritage.

Poprawe (2015) concluded for a panel of more than 100 cities that corruption negatively impacts tourism. One point increase in scores of corruption perception index (indicating a decrease in corruption) increases tourist inflows by 2 to 7 percent. Moreover GDP per capita, trade openness and temperate climate positively contribute in tourist inflows. Afonso-Rodríguez (2017) evaluated the dynamics and impact of terrorist attacks on tourism and economic

\footnotetext{
* The earlier studies have used different measures of tourism like tourist arrivals (Demir \& Gozgor, 2019; Gokovali \& Bahar, 2006; Gokovali., 2010; Khan \& Rasheed, 2016; Naudé \& Saayman, 2005; Steyn \& Vuuren, 2016), tourism revenue (Khalil et al., 2007), number of hotels, eating and drinking places, and museums (Klein \& Osleeb, 2010), and number of tourists (Su \& Lin, 2014). Yap and Saha (2013) have used tourist arrivals and tourism revenue separately. Similarly Demir and Gozgor (2019) used the number of tourist arrivals and tourist receipts. However, Antonakakis et al. (2016) have measured tourism through an index of international tourism receipts, tourism expenditures and tourist arrivals, and termed it as tourism growth.

${ }^{5}$ We have followed (Yap \& Saha, 2013), who have estimated the impact of political instability index as well as components of political instability on tourism.
} 
growth in Turkey. The study evidenced that terrorism by reducing the demand for inbound tourism negatively impacts real GDP. Even a relatively smaller number of terrorist attacks reduces the real GDP by 10 percent after a delay of three to six months through negative effect of terrorism on tourism demand.

Antonakakis et al. (2016) analyzed the tourism and economic growth in the perspectives of quality of political institutions. The role of political institutions was captured by democratic and non-democratic nature of the economies based on polity IV index. They concluded that democratic countries aggressively encourage investment in different sectors of the economies, and tourism in these countries rapidly flourish by economic growth as compared to non-democratic countries.

Some of the studies have probed the governance and tourism, for example, Steyn and Vuuren (2016) investigated the relationship between governance and tourism (tourist arrivals) for 158 countries. The governance was measured by the six components of governance. They concluded that only four components of governance, i.e. government effectiveness, political stability and the absence of violence/terrorism, rule of law, and control of corruption influence the international tourist arrivals whereas, regulatory quality and voice and accountability does not affect tourist arrivals. It explains that certain components of governance are more valuable for tourism than others. Saha. et al. (2017) analyzed the impact of political and economic freedom on inbound tourism for over 100 countries through fixed effect technique. The political freedom was measured by three variables, i.e. civil liberties, political rights and democratic accountability. The real gross domestic product, real exchange rate, bureaucratic quality, external conflicts and government stability were included in the analysis as control variables. The study concluded that civil liberties and economic freedom positively influence inbound tourism. The moderation effect revealed that civil liberties (economic freedom) tend to play a more influence role in inbound tourism when the level of economic freedom (civil liberties) is relatively low. In the control variables, the bureaucratic quality and government stability increase inbound tourism while external conflicts decrease inbound tourism.

Demir and Gozgor (2019) examined the role of freedom of press on inbound tourism for a panel of 160 countries. They concluded that freedom of press enhances inbound tourism for panel of all countries (see also Das and Dirienzo (2009)) and disaggregated panel of low-income and high-income countries. The GDP per capita, exchange rate and international trade also positively impact inbound tourism for panel of all countries.

Kim et al. (2018) explored the impact of quality of national governance institutions measured by the world governance indicators on tourism inflow and tourism revenue for a panel of 108 countries. They found that high quality of governance attracts more international tourists and drives high revenue from them. The alternative measures of institutional quality, i.e. Political Risk services, bureaucratic quality, and law and order made the results robust. The institutional quality has strong impact on tourism in high income economies as compared to emerging economies. Capturing the governance as an index ${ }^{6}$ and the tourism development as an index along with estimation of the components of governance and indicators of tourism development for a panel of developing economies make the current study distinguished from the previously existed literature.

\section{METHODOLOGY}

To examine the impact of governance on tourism development Dynamic Panel Data GMM (Generalized Method of Moment) technique is applied for a panel of 65 developing economies ${ }^{7}$ covering the time span of $2000-$

\footnotetext{
${ }^{6}$ In this way the governance is the multidimensional (broader) concept by which the authority in a country is exercised (Kaufmann, Kraay, \& Zoido, 2002).

${ }^{7}$ Algeria, Argentina, Bahrain, Bangladesh, Benin, Botswana, Brazil, Burundi, Cameroon, Chad, Chile, China, Colombia, Comoros, Congo, Cost Rica, Egypt, Ethiopia, Gabon, Ghana, Guyana, Haiti, Honduras, Hong Kong, India, Indonesia, Iran, Iraq, Israel, Jamaica, Jordan, Kenya, Kuwait, Lebanon, Libya, Madagascar, Malaysia, Mali, Malawi, Mauritania, Mexico, Morocco, Nepal, Nicaragua, Nigeria, Oman, Pakistan, Panama, Paraguay, Peru, Philippine, Qatar, Saudi Arabia, Senegal, Singapore, South Africa, Sri Lanka, Sudan, Togo, Turkey, Uganda, United Arab Emirate, Uruguay, Yemen, Zimbabwe.
} 
2015. The GMM technique is employed to remove the problem of endogeneity because endogeneity directs to unfair and contradictory estimates that make consistent results impossible.

\subsection{Model Specification}

The functional form of the model is given as:

$$
\text { TOUR }=\mathrm{f}(\text { GOVER, GDP, TERROR, ENVIR, TRAD, CORRP })
$$

The operational definition of the variables and source of data is given in Table 1.

Table-1. Operational definitions of the variables and source of data.

\begin{tabular}{|c|c|c|}
\hline Variables & Operational definitions & Source of data \\
\hline $\begin{array}{ll}\text { TOUR } & \text { (Tourism } \\
\text { development) } & \end{array}$ & $\begin{array}{l}\text { Tourism development is measured by an index of foreign } \\
\text { visitors spending, domestic visitor's spending and tourism } \\
\text { contribution to employment. }\end{array}$ & WTTC (2018) \\
\hline GOVER (Governance) & $\begin{array}{l}\text { Governance is measured by an index of five indicators which } \\
\text { are government effectiveness, political stability, rule of law, } \\
\text { regulatory quality, and voice and accountability. }\end{array}$ & $\begin{array}{l}\text { World } \\
(2018 \mathrm{~b})\end{array}$ \\
\hline $\begin{array}{l}\text { GDP } \\
\text { growth) }\end{array}$ & $\begin{array}{l}\text { Annual percentage growth rate of GDP at market prices } \\
\text { based on constant local currency. }\end{array}$ & World Bank (2018a) \\
\hline TERROR (Terrorism) & $\begin{array}{l}\text { Terrorism is measured by an index of number of fatalities, } \\
\text { number of injuries and number of incidences of terrorism. }\end{array}$ & World Bank (2018a) \\
\hline $\begin{array}{l}\text { ENVIR (Environmental } \\
\text { degradation) }\end{array}$ & $\begin{array}{l}\text { Emission of carbon dioxide }\left(\mathrm{CO}_{2}\right) \text { from fossil fuels (metric } \\
\text { ton per capita) }\end{array}$ & World Bank (2018a) \\
\hline TRAD (Trade openness) & $\begin{array}{l}\text { Trade Openness is the sum of exports and imports of goods } \\
\text { and services measured as a share of gross domestic product. }\end{array}$ & World Bank (2018a) \\
\hline CORRP (Corruption) & $\begin{array}{l}\text { Control of corruption index captures the perception that } \\
\text { public power is exercised for private gain, ranging from }-2.5 \\
\text { to } 2.5 \text { while }-2.5 \text { represents high corruption and } 2.5 \\
\text { represents low corruption }\end{array}$ & $\begin{array}{l}\text { World } \\
(2018 \mathrm{~b})\end{array}$ \\
\hline
\end{tabular}

\subsection{Construction of Variables}

The tourism development, governance and terrorism are measured by indices through principal component analysis ${ }^{8}$. Control of corruption is also a part of governance but it has been included in the analysis as a separate variable in the presence of governance to see its impact on tourism development. In the analysis the inverse of the values for corruption have been used, i.e. higher value represents higher level of corruption. Similarly, the inverse values of government effectiveness, political stability, regulatory quality, rule of law, and voice and accountability have been taken.

Table-2. Indicators of tourism development.

\begin{tabular}{l|l|l}
\hline Variable & Definitions & Source \\
\hline $\begin{array}{l}\text { FSPEND (Foreign visitors } \\
\text { spending) }\end{array}$ & Spending within a country by international tourists & WTTC (2018) \\
\hline $\begin{array}{l}\text { DSPEND (Domestic visitors } \\
\text { spending) }\end{array}$ & $\begin{array}{l}\text { Spending within a country by that country's resident } \\
\text { on tourism for business and leisure }\end{array}$ & WTTC (2018) \\
\hline $\begin{array}{l}\text { CEMP (Contribution of } \\
\text { tourism in employment) }\end{array}$ & $\begin{array}{l}\text { The number of jobs generated directly by travel and } \\
\text { tourism }\end{array}$ & WTTC (2018) \\
\hline
\end{tabular}

${ }^{8}$ Although Yap and Saha (2013) have captured the impact of terrorism on tourism by taking terrorist attacks as a proxy of terrorism. The severity of the attacks is missing in this proxy, that is why we have created an index for terrorism by including the number of casualties, injuries and incidents. 
Table-3. Indicators of governance index.

\begin{tabular}{|c|c|c|}
\hline Variable & Definitions & Source \\
\hline $\begin{array}{l}\text { GEFFECT } \\
\text { (Government } \\
\text { effectiveness) }\end{array}$ & $\begin{array}{l}\text { Government effectiveness captures perception of the quality of public } \\
\text { services, the quality of the civil services and the degree of its freedom } \\
\text { from political strains, the quality of policy formulation and } \\
\text { accomplishment, and the reliability of the government's promises to } \\
\text { such policies. The index ranges from }-2.5 \text { to } 2.5 \text { while }-2.5 \text { represents } \\
\text { high level of government effectiveness and } 2.5 \text { represents low level of } \\
\text { government effectiveness. }\end{array}$ & World Bank. (2018b) \\
\hline $\begin{array}{l}\text { PSTAB } \\
\text { (Political } \\
\text { stability) }\end{array}$ & $\begin{array}{l}\text { Political stability and absence of violence measures perception of the } \\
\text { possibility of political instability or politically motivated violence, } \\
\text { which includes terrorism through an index. It ranges from }-2.5 \text { to } 2.5 \\
\text { while }-2.5 \text { represents high political stability and } 2.5 \text { represents low } \\
\text { political stability. }\end{array}$ & World Bank. (2018b) \\
\hline $\begin{array}{l}\text { RQUAL } \\
\text { (Regulatory } \\
\text { quality) }\end{array}$ & $\begin{array}{l}\text { Regulatory quality confines perception of the capability of the } \\
\text { government to develop and implement sound policies and regulations } \\
\text { that allow and encourage private sector development. The index } \\
\text { ranges from }-2.5 \text { to } 2.5 \text { while }-2.5 \text { represents high level of regulator } \\
\text { quality and } 2.5 \text { represents low level of regulatory quality. }\end{array}$ & World Bank. (2018b) \\
\hline $\begin{array}{l}\text { RULE } \\
\text { (Rule of law) }\end{array}$ & $\begin{array}{l}\text { Rule of law captures perception of the extent on which agents have } \\
\text { confidence in and abide by the rules of civilization, and in particular } \\
\text { the quality of agreement enforcement, property rights, the police, and } \\
\text { the magistrates, as well as the probability of crime and violence. The } \\
\text { index ranges from }-2.5 \text { to } 2.5 \text { while }-2.5 \text { represents high level of rule } \\
\text { of law and } 2.5 \text { represents low level of rule of law. }\end{array}$ & World Bank. (2018b) \\
\hline $\begin{array}{l}\text { VOICE } \\
\text { (Voice and } \\
\text { accountability) }\end{array}$ & $\begin{array}{l}\text { Voice and accountability capture opinion on the extent to which a } \\
\text { country's people are able to contribute in selecting their government, } \\
\text { as well as freedom of expression, freedom of organization, and a free } \\
\text { media. The index ranges from }-2.5 \text { to } 2.5 \text { while }-2.5 \text { represents high } \\
\text { level of voice and accountability and } 2.5 \text { represents low level of voice } \\
\text { and accountability. }\end{array}$ & World Bank. (2018b) \\
\hline
\end{tabular}

Table-4. Indicators of terrorism index.

\begin{tabular}{|c|c|c|}
\hline Variable & Definition & Source \\
\hline $\begin{array}{l}\text { NFATAL } \\
\text { (Number of fatalities) }\end{array}$ & $\begin{array}{l}\text { The number of total confirmed fatalities for the incident. The number } \\
\text { includes all victims and attackers who died as a direct result of the } \\
\text { incident. }\end{array}$ & GTD (2018) \\
\hline $\begin{array}{l}\text { NINJUR } \\
\text { (Number of injuries) }\end{array}$ & $\begin{array}{l}\text { The number of confirmed non-fatal injuries to both perpetrators and } \\
\text { victims. }\end{array}$ & GTD (2018) \\
\hline $\begin{array}{l}\text { NINCID } \\
\text { (Number of incidents) }\end{array}$ & The number of total incident occurred. & GTD (2018) \\
\hline
\end{tabular}

\subsection{Data Source}

The dataset of 65 developing economies gathered from various sources, i.e. World Development Indicators World Bank (2018a), Worldwide Governance Indicators (World Bank., 2018b); WTTC (2018) and the GTD (2018) covers the time period of 2000 to 2015 . The variables of terrorism was having some missing values so a new variable of terrorism is generated by using linear interpolation through STATA.

\subsection{Econometric Modeling}

In the non-stationary panel series having time trends and shocks, the explained variables cannot be regressed on explanatory variables. If they are regressed the emerged results may be spurious and unreliable. To make the current series stationary (Levin, Lin, \& Chu, 2002) test for panel unit root is applied.

To estimate the relationship between governance and tourism development the dynamic GMM panel estimation is used. It was introduced by Arellano and Bond (1991) and further developed by Arellano and Bover (1995) and Blundell and Bond (1998). 
The Hausman test is applied to detect the endogeneity problem in the variables of the dynamic regression model. Furthermore, the Arellano and Bond (1991) test is applied to remove the autocorrelation.

The Sargan test is applied to check the validity of instrumental variables. The hypothesis being tested with the Sargan test is that the instrumental variables are uncorrelated to some set of residuals and therefore they are acceptable and healthy instruments.

\subsection{Econometric Specification of the Model}

The econometric form of model for the panel is given as:

TOUR $_{\text {it }}=\beta_{0}+\beta_{1}$ GOVER $_{\text {it }}+\beta_{2}$ GDP $_{\text {it }}+\beta_{3}$ TERROR $_{\text {it }}+\beta_{4}$ ENVIR $_{\text {it }}+\beta_{5}$ TRADE $_{\text {it }}+\beta_{6}$ CORRP $_{\text {it }}+\varepsilon_{\text {it }} \ldots$ (2) Where i represents individual country, and t represents time period.

The same model is regressed for components of tourism development, i.e. FSPEND $_{\text {it }}=$ foreign visitors spending, $\mathrm{DSPEND}_{\mathrm{it}}=$ domestic tourists spending, and $\mathrm{CEMP}_{\mathrm{it}}=$ tourism contribution in employment.

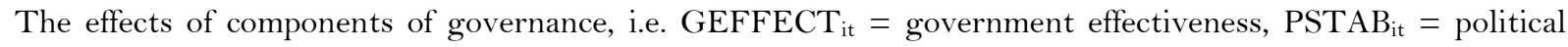
stability, RQUAL $\mathrm{R}_{\mathrm{it}}=$ regulatory quality, $\mathrm{RULE}_{\mathrm{it}}=$ rule of law and $\mathrm{VOICE}_{\mathrm{it}}=$ voice and accountability on tourism development along with control variables are also estimated.

\section{RESULTS AND DISCUSSION}

\subsection{Results of Panel Unit Root}

The results of Levin et al. (2002) panel unit root test in Table 5 show that all the variables are stationary at level for panel analysis.

Table-5. Results of panel unit root test.

\begin{tabular}{|c|c|c|}
\hline \multirow[t]{3}{*}{ Variables } & \multirow{2}{*}{\multicolumn{2}{|c|}{$\begin{array}{c}\text { At level } \\
\text { Levin, Lin, Chu }\end{array}$}} \\
\hline & & \\
\hline & Statistics & Prob. \\
\hline TOUR (Tourism development) & -1.1002 & 0.0000 \\
\hline GOVER (Governance) & -51.8858 & 0.0000 \\
\hline GDP (Economic growth) & -13.059 & 0.0000 \\
\hline TERROR (Terrorism) & -2.3790 & 0.0087 \\
\hline ENVIOR (Environmental degradation) & 4.0001 & 0.0000 \\
\hline TRAD (Trade openness) & -53.96 & 0.0000 \\
\hline CORRP (Corruption) & -71.6478 & 0.0000 \\
\hline GEFFECT (Government effectiveness) & -74.2963 & 0.0000 \\
\hline PSTAB (Political stability) & -65.3860 & 0.0000 \\
\hline RQUAL (Regulatory quality) & -81.4282 & 0.0000 \\
\hline RULE (Rule of law) & -64.1674 & 0.0000 \\
\hline VOICE (Voice and accountability) & -91.139 & 0.0000 \\
\hline FSPEND (Foreigners spending) & -2.0001 & 0.0000 \\
\hline DSPEND (Domestic spending) & -91.5199 & 0.0000 \\
\hline CEMP (Employment contribution) & -45.5803 & 0.0000 \\
\hline
\end{tabular}

\subsection{GMM Results for Tourism Development}

The GMM estimates of six models in Table 6 express that majority of the results are theoretically supportive for tourism development. The Hausman test detects the endogeneity problem in the analysis. The value of chisquare is less than 0.05 which means endogeneity problem exists in the model. The Sargan test verify the validity of instrument variables as the $\mathrm{j}$-statistic is 1.00 that is greater than $5 \%$. 
Table-6. Results of GMM for tourism development.

\begin{tabular}{|c|c|c|c|c|c|c|}
\hline \multicolumn{7}{|c|}{ Dependent variable: Tourism Development } \\
\hline Variables & Model (1) & Model (2) & Model (3) & Model (4) & Model (5) & Model (6) \\
\hline $\begin{array}{ll}\text { TOUR }(-1) & \text { (Tourism } \\
\text { Development) } & \\
\end{array}$ & $\begin{array}{l}0.5930^{*} \\
(0.000)\end{array}$ & $\begin{array}{l}0.5968^{*} \\
(0.000)\end{array}$ & $\begin{array}{l}0.5105^{*} \\
(0.000)\end{array}$ & $\begin{array}{l}0.5231^{*} \\
(0.000)\end{array}$ & $\begin{array}{l}0.5145^{*} \\
(0.000)\end{array}$ & $\begin{array}{l}0.5267^{*} \\
(0.000)\end{array}$ \\
\hline $\begin{array}{l}\text { GOVER } \\
\text { (Governance) }\end{array}$ & $\begin{array}{l}5.9066^{*} \\
(0.000)\end{array}$ & & & & & \\
\hline $\begin{array}{l}\text { GEFECT } \\
\text { (Government } \\
\text { effectiveness) }\end{array}$ & & $\begin{array}{c}2.7172^{*} \\
(0.000)\end{array}$ & & & & \\
\hline $\begin{array}{l}\text { PSTAB } \\
\text { (Political stability) }\end{array}$ & & & $\begin{array}{l}2.5583^{*} \\
(0.000)\end{array}$ & & & \\
\hline $\begin{array}{l}\text { RQUAL } \\
\text { (Regulatory quality) }\end{array}$ & & & & $\begin{array}{l}2.9082^{*} \\
(0.000)\end{array}$ & & \\
\hline $\begin{array}{l}\text { RULE } \\
\text { (Rule of law) }\end{array}$ & & & & & $\begin{array}{l}2.9521 * \\
(0.000)\end{array}$ & \\
\hline $\begin{array}{l}\text { VOICE } \\
\text { (Voice and accountability) }\end{array}$ & & & & & & $\begin{array}{l}2.1785^{*} \\
(0.000)\end{array}$ \\
\hline GDP (Economic growth) & $\begin{array}{c}0.0277^{*} * \\
(0.050)\end{array}$ & $\begin{array}{c}0.03756^{*} \\
(0.014) \\
\end{array}$ & $\begin{array}{c}0.0050^{*} \\
(0.000)\end{array}$ & $\begin{array}{c}0.0115^{*} \\
(0.000)\end{array}$ & $\begin{array}{c}0.0181^{*} \\
(0.000)\end{array}$ & $\begin{array}{c}0.0228^{*} \\
(0.000)\end{array}$ \\
\hline TERROR (Terrorism) & $\begin{array}{c}-0.0013^{*} \\
(0.007)\end{array}$ & $\begin{array}{c}-0.0029 * \\
(0.000)\end{array}$ & $\begin{array}{c}-0.0002^{*} \\
(0.000)\end{array}$ & $\begin{array}{c}-0.0003^{*} \\
(0.000)\end{array}$ & $\begin{array}{c}-0.0002^{*} \\
(0.000)\end{array}$ & $\begin{array}{c}-0.0002^{*} \\
(0.000)\end{array}$ \\
\hline $\begin{array}{l}\text { ENVIOR (Environmental } \\
\text { degradation) }\end{array}$ & $\begin{array}{c}-0.40953^{*} \\
(0.000)\end{array}$ & $\begin{array}{c}-0.3474^{*} \\
(0.000)\end{array}$ & $\begin{array}{c}-0.7044^{*} \\
(0.000)\end{array}$ & $\begin{array}{c}-0.6721^{*} \\
(0.000)\end{array}$ & $\begin{array}{c}-0.6791^{*} \\
(0.000)\end{array}$ & $\begin{array}{c}-0.6092^{*} \\
(0.000)\end{array}$ \\
\hline TRAD (Trade openness) & $\begin{array}{c}0.00101 \\
(0.266)\end{array}$ & $\begin{array}{c}0.0015^{*} \\
(0.022)\end{array}$ & $\begin{array}{c}0.0013^{*} \\
(0.000)\end{array}$ & $\begin{array}{c}0.0012^{*} \\
(0.000)\end{array}$ & $\begin{array}{c}0.0012^{*} \\
(0.000)\end{array}$ & $\begin{array}{c}0.0013^{*} \\
(0.000)\end{array}$ \\
\hline CORRP (Corruption) & $\begin{array}{c}-2.349^{* * * *} \\
(0.083) \\
\end{array}$ & $\begin{array}{c}-1.0433 * * \\
(0.053) \\
\end{array}$ & $\begin{array}{c}-0.7826^{*} \\
(0.002)\end{array}$ & $\begin{array}{c}-1.7390^{*} \\
(0.000) \\
\end{array}$ & $\begin{array}{c}-1.5739^{*} \\
(0.000) \\
\end{array}$ & $\begin{array}{c}-0.4729^{*} \\
(0.003) \\
\end{array}$ \\
\hline Chi square & 0.0000 & 0.0000 & 0.0000 & 0.0000 & 0.0000 & 0.0000 \\
\hline J-Statistic & $\begin{array}{l}38.74^{*} \\
(1.000)\end{array}$ & $\begin{array}{l}36.69^{*} \\
(1.00)\end{array}$ & $\begin{array}{l}60.08^{*} \\
(1.00)\end{array}$ & $\begin{array}{l}57.96^{*} \\
(1.00)\end{array}$ & $\begin{array}{l}60.46^{*} \\
(1.00)\end{array}$ & $\begin{array}{l}58.90^{*} \\
(1.000)\end{array}$ \\
\hline Observation & 576 & 576 & 882 & 882 & 882 & 882 \\
\hline
\end{tabular}

\subsubsection{Governance}

The results of model 1 showing the impact of governance (captured by an index of five governance indicators) on tourism development show that governance positively influences tourism development. It explains that government institutions manage most of the development needed for tourism. Moreover, the efficient government has holistic and sensible approach towards tourism (Dredge \& Jenkins, 2007). It further explains that tourism development depends upon the institutional efficiency, efficient utilization of resources and skills, quality of public service, quality of policy formulation and accomplishment, and capacity of government to develop and implement policies and regulations. The results suggest that when the countries are suffering from bad governance, the tourists switch their travel destination to other countries where there exists good governance.

Model 2 captures the impact of government effectiveness that is one of the components of governance on tourism development. The government effectiveness positively affects tourism development. It enlightens that government effectiveness that is comprised of the quality of public service, quality of civil service, lacking of political strains on decision-making, policy formulation and its implementation boosts up the tourism development. It is consistent with the theory which predicts that government effectiveness in the form of the quality of public service, and quality of the civil services reduce the rent seeking behavior and increases the facilities for improvement in tourism services which attract the tourists. Operationally, the decision-making, policy formulation and its implementation without political interventions enhance the efficiency of all sections of the economy, which results into well-established system and infrastructure for tourism development along with other sectors development. The result is corroborated by the findings of Saha. et al. (2017) that higher level of bureaucratic quality increases the number of tourists and revenue from tourism. The impact of political stability on tourism 
development captured in model 3 represents that political stability enhances tourism development. The political stability encapsulated by the political attributes of the destination country is seriously considered by the international tourists while deciding their destination. The tourists believe that politically instable countries are riskier to travel and stay. They may fall in an unexpected explosion of political violence. The earlier studies explained that political stability and political relations within and among states are important factors for determining the destination of tourism by tourists. The politically instable countries are facing alarming situation of tourism (Fletcher \& Morakabati, 2008). Yap and Saha (2013) evidenced that components of political instability like the internal conflict, external conflict, military in politics and ethnic tension negatively affect tourist arrivals and tourism revenue. It explains that absence of political instability and particularly non-existence of motivated violence are the prerequisites of tourism development (see also Naudé and Saayman (2005) for Africa).

The regulatory quality is found positively influencing tourism development in model 4 . The establishment of regulatory quality and institutional framework liberalize the tourism sector (Gray, 1998), which develops the tourism industry through encouraging private investment in hotels, transportation and tourist's other requisites. The regulatory quality improves the facilities, services and administrative skills. The process augments tourism development. Since regulatory quality force the tourism industry to provide good quality of tourist services it gives strong incentive for the tourists to enjoy tourism. Thus the spending by the foreign and domestic tourists are increased which increases the contribution of employment by the tourism sector.

The model 5 concludes that rule of law increases tourism development. It explains that if rules and regulations are properly implemented in the economies, it enhances the development of civil society, increases the performance of institutions and organizations and decreases the probability of crimes and violence which ultimately creates an atmosphere of confidence for the tourists. In this way foreign and domestic tourists are attracted and there emerged a boost in tourism development. On the other hand the tourists are generally concerned about getting into trouble in a regime with weak rule of law as it is associated with weak rules of civilization as well as probability of crimes and violence. The negative reputation of a country due to poor status of rule of law discourages the tourist's desire to visit that country. The business tourists particularly face the disadvantages of poor status of rule of law in the host country. They fear of victimization of weak law enforcement system and bearing harsh penalty due to some business disputes with the local business community. Generally, in the presence of poor rule of law in the economies the tourists remain in afraid of being punished for trivial offence or for being in the wrong place at the wrong time during crackdowns. The results of model 6 indicate a positive effect of voice and accountability on tourism development. Voice and accountability captures the extent of the people for democracy, freedom of organization, freedom of expression and free media. Yap and Saha (2013) explained that voice and accountability demonstrate the tendency towards democratic values, political and personal freedom. The inverse to the democratic values, i.e. the interventions of military in government matters adversely affect the tourism. Steyn and Vuuren (2016) explained that voice and accountability of the economies boot the inbound tourism. Gholipour, Tajaddini, and Al-Mulali (2014) pointed out that if freedom is scarce or suppressed by the rulers in a country, the local people value the freedom more. They demand it in other countries. Corollary the countries with higher level of freedom attract more international tourists. Demir and Gozgor (2019) established that freedom of media contributes to tourism. The freedom of media as a part of voice and accountability focuses on the ways to increase the tourism in the economies.

\subsubsection{Economic Growth}

There is a strong theoretical background for inclusion of economic attributes of destination country for tourism. The economic growth is an important proxy for economic attributes to see its effect on tourism development, although (Saha. et al., 2017; Yap \& Saha, 2013) have used GDP per capita to capture the effect of economic development. The estimates show that economic growth of the destination country positively influence the tourism development in all the six specifications. It explains that economic growth has direct and indirect 
effects on tourism development. It makes the government capable to spend more on tourism sector which develops tourism directly and increase in GDP per capita raises the foreign visitor's inflow indirectly due to higher standard of living in the host country (Poprawe, 2015). It is evidenced by Naudé and Saayman (2005) and Rasekhi and Mohammadi (2015) that GDP per capita growth has encouraging effect on tourism as growth of an economy leads to developed transport system, airline, roads, and conservation of nature and preservation of heritage etc. which increases foreign tourists visits. Khalil et al. (2007) explained that economic growth affects tourism due to improved and well-established infrastructure and tourist resorts in the host country.

\subsubsection{Terrorism}

The terrorism has shown negative effect on tourism development in all the specifications. It is a harmful phenomenon for tourism because it endangers tourist's arrivals, stay and mobility. The number of terrorist attacks, the injuries and causalities create threat, harassment and fear of insecurity and violence in the economy as a result tourism development declines. It is evidenced in the literature that civil war, terrorism, crimes and harassment produce pessimistic effect on tourists. The effect is greater on leisure tourism rather than business tourism, even the business tourism squeezes down due to terrorism. The terrorist attacks adversely affect tourism (Khan \& Rasheed, 2016; Yap \& Saha, 2013). The other explanation may be that due to terrorism most of the resources are consumed by military to guard the people against terrorism, so governments spend less on tourism industry (Niskanen, 2006) which badly affects tourism development. Furthermore, terrorists damage the tourist spots to spread the harassment internationally.

\subsubsection{Environmental Degradation}

In all the specifications, the environmental degradation captured by $\mathrm{CO}_{2}$ emission negatively influences tourism development. It is based on the fact that $\mathrm{CO}_{2}$ emission pollutes the environment and tourists avoid traveling in environmentally polluted areas. Leitieo and Muhammad (2016) explained that there is negative relationship between climate change and tourism. Turan, Mete, and Ceyhun (2014) also found that $\mathrm{CO}_{2}$ emission damages the climate and negatively influence tourism.

\subsubsection{Trade Openness}

The trade openness has been found positively influencing tourism development in all the specifications. The results are in line with the findings of Poprawe (2015) and Demir and Gozgor (2019). The higher level of trade openness means higher level of economic ties with the rest of world which promotes tourism development. The trade openness is particularly attached with business tourism so by trade openness the economies can have the benefits of tourism.

\subsubsection{Corruption}

Corruption has been included in the analysis as a separate explanatory variable along with governance. The corruption negatively affects tourism in all the specifications of model. It explains that when tourists have to pay bribes during holidays or a business tour, the cost of travelling, accommodation and tourism increases (Poprawe, 2015) which results into decreased tourism. Corruption declines the quality of public infrastructure and becomes the cause of low tourism development. Saha and Yap (2015) and Khan and Rasheed (2016) indicated that public infrastructure and tourism infrastructure are important components of development of tourism and they can be used efficiently only by elimination of corruption. However, Yap and Saha (2013) explained that corruption does not affect tourism in the economies where natural and historical heritage exist. 


\subsection{GMM Results for Indicators of Tourism}

In this section the effect of governance on indicators of tourism development, i.e. foreign visitors spending, domestic tourists spending and tourism contribution to employment are discussed.

Table-7. Results of GMM for Indicators of Tourism.

\begin{tabular}{|c|c|c|c|}
\hline \multicolumn{4}{|c|}{$\begin{array}{l}\text { Dependent variables: Tourism indicators (Foreign visitor's spending, Domestic tourists spending, } \\
\text { Employment contribution). }\end{array}$} \\
\hline Variables & $\begin{array}{c}\text { Model (1) } \\
\text { Foreign visitors } \\
\text { spending } \\
\end{array}$ & $\begin{array}{c}\text { Model (2) } \\
\text { Domestic tourists } \\
\text { spending } \\
\end{array}$ & $\begin{array}{c}\text { Model (3) } \\
\text { Employment } \\
\text { contribution } \\
\end{array}$ \\
\hline Tourism indicators $(-1)$ & $0.4974(0.000)(-1)$ & $0.5753(0.000)(-1)$ & $0.5791(0.000)(-1)$ \\
\hline GOVER (Governance) & $5.3291 *(0.000)$ & $0.7211 *(0.000)$ & $3.8031 *(0.000)$ \\
\hline GDP (Economic growth) & $0.017143 *(0.000)$ & $-0.0219 *(0.000)$ & $0.0132 *(0.000)$ \\
\hline TERROR (Terrorism) & $-0.00058^{*}(0.000)$ & $-0.0028 *(0.000)$ & $-0.0022 *(0.000)$ \\
\hline ENVIOR (Environmental degradation) & $-0.71077^{*}(0.000)$ & $-0.0994 *(0.000)$ & $-0.1799 *(0.000)$ \\
\hline TRAD (Trade openness) & $0.00078 *(0.000)$ & $0.00071 *(0.000)$ & $0.0034 *(0.000)$ \\
\hline CORRP (Corruption) & $-1.5149 *(0.000)$ & $-0.5368 *(0.000)$ & $-1.0856 *(0.006)$ \\
\hline Chi square & 0.0000 & 0.0000 & 0.0000 \\
\hline J-Statistic & $58.13 *(1.00)$ & $37.41 *(1.00)$ & $36.48 *(1.00)$ \\
\hline Observation & 576 & 576 & 882 \\
\hline
\end{tabular}

Note: * indicates 1 percent level of significance (Prob. values are in parentheses).

The results in Table 7 show that governance positively affects foreign visitors spending, domestic tourists spending and employment contribution. It explains that good governance increases all indicators of tourism development. The results are corroborated by the estimates of previous regression where governance (as an index) and the components of governance have positive impact on tourism development. The governments through good governance may exert positive impact on tourism by rational spending on infrastructure, parks and heritage (Dredge \& Jenkins, 2007). By good governance the spending on public and private sector is rationally allocated and utilized, so the spending on tourism sector and other related sectors increases tourism contribution in employment (Katircioğlu., 2011; Tang, Selvanathan, \& Selvanathan, 2007).

The economic growth has shown positive effect on two components of tourism in their respective models. They are foreign visitors spending and employment contribution. However, the economic growth has shown negative impact on domestic tourism spending. The explanation for negative effect of GDP growth on domestic visitors spending on tourism may be that by increase in economic growth the standard of living of the people goes up and they prefer international tourism rather than domestic tourism. So increase in growth of economy particularly in the developing countries tends to lead decline in the domestic spending on tourism. However, higher GDP growth rate increases the spending of public and private sector on tourism industry along with investment in other industries. It creates job opportunities through the extension of tourism infrastructure like hotels, restaurants and transport. Ultimately, it enhances the contribution of tourism in employment.

Terrorism negatively affects all indicators of tourism development, i.e. visitor's spending, domestic spending and employment generation. Terrorism not only reduce leisure tourism but also diminishes the worldwide business tourism. The terrorism initiates the process of anti-globalization. Terrorism slides down the domestic tourism as well. People feel fear to travel when their lives are in danger. The terrorism negatively affects the tourism contribution to employment. When terrorism increases in any tourist destination it creates harassment and fear and lowers the investment in tourism which decreases the employment contribution of tourism.

The environmental degradation captured by $\mathrm{CO}_{2}$ emission negatively affects all the components of tourism corroborating the results of previous section. Turan et al. (2014) also found that $\mathrm{CO}_{2}$ emission has negative effect on climate change and negative effect on tourism. The environmental degradation has also negative effect on share 
of tourism in employment. The reason is that environmental degradation squeezes the tourism sector which decreases employment contribution of tourism.

The trade openness positively influences foreign visitor's spending, domestic tourists spending and employment contribution. It is supported by the results of previous section, where trade openness positively affects the tourism development. Kulendran and Wilson (2000) evidenced that trade is one of the most important factors of tourism. The promotion of trade policies by the government increases business tourism. The business community move and travel for business. The trade policy basically focuses on development of roads and rail lines and provision of transportation services at low fare which increases business tourism internationally and domestically. Hong Kong has well-known repute as a shopping glory for mainland Chinese tourists. She is offering a variety of duty free shopping opportunities from lavishness goods to daily provisions. So the development of trade increases tourism and employment opportunities. Corruption has shown negative effect on all the three indicators of tourism, i.e. foreign visitor's spending, domestic spending and employment contribution. The estimates of previous regression where corruption negatively affects the tourism development, supported the results. Poprawe (2015) has shown negative effect of corruption on visitors spending. Corruption lessens the quality of public infrastructure and becomes the cause of low foreign visitors spending, domestic spending and contribution of tourism in employment.

\section{CONCLUSION AND POLICY RECOMMENDATIONS}

The study focused to see the impact of governance on tourism development for a panel of 65 developing countries covering the time span of 2000 to 2015 and employing the generalized method of moment for estimation. Governance is measured by an index comprised of the components like government effectiveness, political stability, regulatory quality, rule of law, and voice and accountability. Tourism development is also measured by an index of three indicators, i.e. foreign visitors spending, domestic tourist spending and contribution of tourism in employment. Both indices are constructed through principal component analysis. It is concluded that governance has positive effect on tourism development as well as components of tourism, i.e. foreign visitors spending, domestic spending and contribution of tourism in employment. It is also concluded that all governance indicators, i.e. government effectiveness, political stability, regulatory quality, rule of law and voice and accountability propagate tourism development. The terrorism, environmental degradation and corruption devastate tourism in developing economies, whichever the measure of tourism is taken in the analysis. However, the trade openness improves tourism for all the measures of tourism, i.e. tourism development in the form of index, foreign visitors spending, domestic tourists spending and contribution of tourism in employment. The governments should improve governance for tourism development. It is proposed to the public sector managers to regulate their institutions, improve the quality of public service, enhance the capacity for accomplishment of programs and policies, encourage the private sector development in tourism, increase political stability and make effective policies for the development of tourism. It is needed to improve the environmental conditions of the economies through regulations for environment protection and conservation of nature. Corruption and terrorism should be vanished by implementation of rules, decision-making about elimination of terrorism free of political strains and improving the quality of law-enforcing agencies.

Funding: This study received no specific financial support.

Competing Interests: The authors declare that they have no competing interests.

Acknowledgement: All authors contributed equally to the conception and design of the study.

\section{REFERENCES}

Adnan, H. Q. M., \& Ali, K. R. E. (2013). Tourism-led growth hypothesis: A case study of Pakistan. Asia Pacific Journal of Tourism Research, 18(4), 303-313. Available at: https://doi.org/10.1080/10941665.2012.658412. 
Afonso-Rodríguez, J. A. (2017). Evaluating the dynamics and impact of terrorist attacks on tourism and economic growth for Turkey. Journal of Policy Research in Tourism, Leisure and Events, 9(1), 56-81.

Ahmad, Z., \& Saleem, A. (2014). Impact of governance on human capital. Pakistan Journal of Commerce and Social Sciences, 8(3), 612-628.

Antonakakis, N., Dragouni, M., Eeckels, B., \& Filis, G. (2016). Tourism and economic growth: Does democracy matter? Annals of Tourism Research, 61, 258-264. Available at: https://doi.org/10.1016/j.annals.2016.09.018.

Arellano, M., \& Bond, S. (1991). Some tests of specification for panel data: Merno carlo evidence and an application to employment equation. The Review of Economic Studies, 58(2), 277-297. Available at: https://doi.org/10.2307/2297968.

Arellano, M., \& Bover, O. (1995). Another look at the instrumental variable estimation of error-components models. Journal of Econometrics, 68(1), 29-5 1. Available at: https://doi.org/10.1016/0304-4076(94)01642-d.

Balaguer, J., \& Cantavella-Jorda, M. (2002). Tourism as a long-run economic growth factor: The Spanish case. Applied Economics, 34(7), 877-884. Available at: https://doi.org/10.1080/00036840110058923.

Blundell, R., \& Bond, S. (1998). Initial conditions and moment restrictions in dynamic panel data models. Journal of Econometrics, 87(1), 115-143. Available at: https://doi.org/10.1016/s0304-4076(98)00009-8.

Brown, F., \& Hall, D. (2008). Tourism and development in the Global South: The issues. Third World Quarterly, 29(5), 839-849.

Can, M., \& Gozgor, G. (2018). Revisiting the tourism-growth nexus: Evidence from a new index for the market diversification of tourist arrivals. Current Issues in Tourism, 21(10), 1157-1170. Available at: https://doi.org/10.1080/13683500.2016.1268103.

Cheung, Y. H. Y., \& Saha, S. (2015). Exploring the nexus between tourism demand and cultural similarity. Tourism Analysis, 20(2), 229-241. Available at: https://doi.org/10.3727/108354215x 14265319207551.

Das, J., \& Dirienzo, C. (2009). Global tourism competitiveness and freedom of the press: A nonlinear relationship. Journal of Tourism Research, 47(4), 470-790. Available at: https://doi.org/10.1177/0047287508326535.

Demir, E., \& Gozgor, G. (2019). Does freedom of the press enhance inbound tourism? Current Issues in Tourism, 21(20), 25502565. Available at: https://doi.org/10.1080/13683500.2018.1470608.

Dredge, D., \& Jenkins, J. (2007). Tourism and policy and planning milton: A methodology for the integration of tourism in town planning. Journal of Tourism Studies, 3(1), 8-21.

Fayos-Sola, E. (2002). Globlzation, tourism policy and tourism education. Acta Turistica, 14(1), 18-20.

Fielding, D., \& Shortland, A. (2011). How do tourists react to political violence? An empirical analysis of tourism in Egypt. Defence and Peace Economics, 22(2), 217-243. Available at: https://doi.org/10.1080/10242694.2011.542340.

Fischhoff, B., De Bruin, W. B., Perrin, W., \& Downs, J. (2004). Travel risks in a time of terror: Judgments and choices. Risk Analysis: An International Journal, 24(5), 1301-1309. Available at: https://doi.org/10.1111/j.0272-4332.2004.00527.x.

Fletcher, J., \& Morakabati, Y. (2008). Tourism activity, terrorism and political instability within the commonwealth: The Cases of Fiji and Kenya. International Journal of Tourism Research, 10(6), 537-556. Available at: https://doi.org/10.1002/jtr.699.

Gholipour, H. F., Tajaddini, R., \& Al-Mulali, U. (2014). Does personal freedom influence outbound tourism? Tourism Management, 41, 19-25. Available at: https://doi.org/10.1016/j.tourman.2013.08.010.

Gokovali, U., \& Bahar, O. (2006). Contribution of tourism to economic growth: A panel datga approach. Anatolia: International Journal of Tourism and Hospitality Research, 17(2), 155-167. Available at: https://doi.org/10.1080/13032917.2006.9687184.

Gokovali., U. (2010). Contribution of tourism to economic growth in Turkey. Anatolia: An International Journal of Tourism and Hospitality Research, 21(1), 139-153. Available at: https://doi.org/10.1080/13032917.2010.9687095.

Goymen, K. (2000). Tourism and governance in Turkey. Annals of Tourism Research, 27(14), 1021-1048. Available at: https://doi.org/10.1016/s0160-7383(99)00127-9.

Gray, M. (1998). Economic reform, privatization and tourism in Egypt. Middle Eastern Studies, 34(2), 91-112. Available at: https://doi.org/10.1080/00263209808701224. 
GTD. (2018). National Consortium for the study of terrorism and responses to terrorism (START). Retrieved from: https://www.start.umd.edu/gtd.

Islam, F., \& Carlsen, J. (2012). Tourism in rural Bangladesh: Unlocking opportunities for poverty alleviation? Tourism Recreation Research, 37(1), 37-45. Available at: https://doi.org/10.1080/02508281.2012.11081686.

Katircioglu, S. T. (2009). Revisiting the tourism-led-growth hypothesis for Turkey using the bounds test and Johansen approach for cointegration. Tourism Management, 30(1), 17-20. Available at: https://doi.org/10.1016/j.tourman.2008.04.004.

Katircioğlu., S. T. (2011). Tourism and growth in Singapore: New extension from bounds test to level relationships and conditional Granger causality tests. The Singapore Economic Review, 56(03), 441-453. Available at: https://doi.org/10.1142/s0217590811004365.

Kaufmann, D., Kraay, A., \& Zoido, P. (2002). Governance matters II: Update indicators for 2000/2001. Working Paper No. 2772. Washington, DC: The World Bank.

Khalil, S., Kakar, M. K., \& Malik, A. (2007). Role of tourism in economic growth: Empirical evidence from Pakistan economy [with comments]. The Pakistan Development Reviere, 46(4), 985-995. Available at: https://doi.org/10.30541/v46i4iipp.985-995.

Khan, R. E. A., \& Rasheed, M. K. (2016). Political economy of tourism in Pakistan: The role of terrorism and infrastructure development. Asian Development Policy Reviere, 4(2), 42-50. Available at: https://doi.org/10.18488/journal.107/2016.4.2/107.2.42.50.

Kim, Y.-R., Saha, S., Vertinsky, I., \& Park, C. (2018). The impact of national institutional quality on international tourism inflows: A cross-country evidence. Tourism Analysis, 23(4), 533-551. Available at: https://doi.org/10.3727/108354218x15391984820503.

Klein, Y. L., \& Osleeb, J. (2010). Determinants of coastal tourism: A case study of Florida beach counties. Journal of Coastal Research, 26(6), 1149-1156. Available at: https://doi.org/10.2112/jcoastres-d-09-00152.1.

Kulendran, N., \& Wilson, K. (2000). Is there a relationship between international trade and international travel? Applied Economics, 32(8), 1001-1009. Available at: https://doi.org/10.1080/000368400322057.

Leitieo, C. N., \& Muhammad, S. (2016). Economic growth, tourism arrivals and climate change. Bulletin of Energy Economic, 4 (1), $35-43$.

Levin, A., Lin, C.-F., \& Chu, C.-S. J. (2002). Unit root tests in panel data: Asymptotic and finite-sample properties. Journal of Econometrics, 108(1), 1-24. Available at: https://doi.org/10.1016/s0304-4076(01)00098-7.

Lv, Z. (2019). Deepening or lessening? The effects of tourism on regional inequality. Tourism Management, 72, 23-26. Available at: https://doi.org/10.1016/j.tourman.2018.11.009.

Mosedale, J. (2014). Political economy of tourism: regulation theory, institutions and governance networks. In Hall, C. M., Lew, A. A. and Williams, A. M. (Eds.). The Wiley-Blackwell companions to tourism (pp. 55-65). West Sussex, UK: WileyBlackwell.

Nassani, A. A., Aldakhil, A. M., Abro, M. M. Q., Islam, T., \& Zaman, K. (2019). The impact of tourism and finance on women empowerment. Journal of Policy Modeling, 41(2), 234-254. Available at: https://doi.org/10.1016/j.jpolmod.2018.12.001.

Naudé, W. A., \& Saayman, A. (2005). Determinants of tourist arrivals in Africa: A panel data regression analysis. Tourism Economics, 11(3), 365-391. Available at: https://doi.org/10.5367/000000005774352962.

Neumayer, E. (2004). Impact of political violence on tourism: Dynamic cross-national estimation. The Journal of Conflict Resolution, 48(2), 259-281. Available at: https://doi.org/10.1177/0022002703262358.

Niskanen, W. (2006). The several costs of responding to the threat of terrorism. Public Choice, 128(1-2), 351-356. Available at: https://doi.org/10.1007/s11127-006-9057-5.

North, D. C. (1990). Institution, institutional change, and economic performance. Cambridge: Cambridge University Press.

Nunkoo, R., Ramkinsoon, H., \& Gursoy, D. (2012). Public trust in tourism institutions. Annals of Tourism Research, 39(3), 15381564. Available at: https://doi.org/10.1016/j.annals.2012.04.004. 
Poprawe, M. (2015). A panel data analysis of the effect of corruption on tourism. Applied Economics, 47(23), 2399-2412. Available at: https://doi.org/10.1080/00036846.2015.1005874.

Rasekhi, S., \& Mohammadi, S. (2015). The relationship between tourism and environmental performance: The case of Caspian Sea Nations. Iranian Journal of Economic Studies, 4(2), 51-81.

Richter, T., \& Steiner, C. (2008). Politics, economics and tourism development in Egypt: Insights into the sectoral transformations of a neo-patrimonial rentier state. Third World Quarterly, 29(5), 939-959. Available at: https://doi.org/10.1080/01436590802106080.

Roy, K. D. (2005). Governance and development: The challenges for Bangladesh. The Bangladesh Development Studies, 31(3,4), 99136.

Saha, S., \& Yap, G. (2015). Corruption and tourism: An empirical investigation in a non-linear framework. International Journal of Tourism Research, 17(3), 272-281. Available at: https://doi.org/10.1002/jtr.1985.

Saha., S., Su, J.-J., \& Campbell, N. (2017). Does political and economic freedom matter for inbound tourism? A cross-national panel data estimation. Journal of Travel Research, 56(2), 221-234. Available at: https://doi.org/10.1177/0047287515627028.

Shafique, S., Haq, R., \& Arif, G. M. (2006). Governance and income inequality [with Comments]. The Pakistan Development Review, 45(4), 751-760.

Shan, J., \& Wilson , K. (2001). Causality between trade and tourism: Empirical evidence from China. Applied Economics Letter, 8(4), 279-283. Available at: https://doi.org/10.1080/135048501750104114.

Steyn, R., \& Vuuren, O. J. (2016). Relationship between quality of governance and foreign tourist numbers. African Journal of Hospitality, Tourism and Leisure, 5(4), 1-10.

Su, Y.-W., \& Lin, H.-L. (2014). Analysis of international tourist arrivals worldwide: The role of world heritage sites. Tourism Management, 40, 46-58. Available at: https://doi.org/10.1016/j.tourman.2013.04.005.

Tang, S., Selvanathan, E. A., \& Selvanathan, S. (2007). The relationship between foreign direct investment and tourism: empirical evidence from China. Tourism Economics, 13(1), 25-39. Available at: https://doi.org/10.5367/000000007779784498.

Turan, K. S., Mete, F., \& Ceyhun, K. (2014). Estimating tourism-induced energy consumption and CO 2 emissions: The case of Cyprus. Renewable and Sustainable Energy Reviews, 29, 634-640. Available at: https://doi.org/10.1016/j.rser.2013.09.004.

Williamson, O. E. (1979). Transaction-cost economics: The governance of contractual relations. The journal of Law and Economics, 22(2), 233-261. Available at: https://doi.org/10.1086/466942.

World Bank. (2018a). World development indicators (WDI) 2018. Retrieved from: https://databank.worldbank.org/source/world-development-indicators. [Accessed January 10, 2018].

World Bank. (2018b). World governance indicators (WGI) 2018.

WTTC. (2018). World travel tourism council (WTTC) 2018. Retrieved from: https://wttc.org/Research/Data-Enquiries-Form. [Accessed January 10, 2018].

Yap, G., \& Saha, S. (2013). Do political instability, terrorism, and corruption have deterring effects on tourism development even in the presence of UNESCO heritage? A cross-country panel estimate. Tourism Analysis, 18(5), 587-599. Available at: https://doi.org/10.3727/108354213x13782245307911.

Zhang, J., \& Jensen, C. (2007). Comparative advantage: Explaining tourism flows. Annals of Tourism Research, 34(1), $223-243$. Available at: https://doi.org/10.1016/j.annals.2006.08.004. 